\section{Efficacy of linezolid against Staphylococcus aureus in different rodent skin and soft tissue infections models}

\author{
Madhvi Rao, ${ }^{1 *}$ Tarani Kanta Barman, ${ }^{1 *}$ \\ Manoj Kumar, ${ }^{1 *}$ Tarun Mathur, ${ }^{1 *}$ \\ Gunjan Shukla, ${ }^{1}$ Ashish Bhati, ${ }^{1}$ \\ Krishna Kishore, ${ }^{1}$ Tridib Chaira, ${ }^{2 \circ}$ \\ Manisha Pandya, ${ }^{1 *}$ Dilip J. Upadhyay ${ }^{1 *}$ \\ 1Department of Infectious Diseases, New \\ Drug Discovery Research, Ranbaxy \\ Research Laboratories, Gurgaon, \\ Haryana; \\ 2Metabolism and Pharmacokinetics \\ Division, New Drug Discovery Research, \\ Ranbaxy Research Laboratories, \\ Gurgaon, Haryana, India
}

\section{Abstract}

Linezolid is approved for complicated and uncomplicated skin and soft tissue infections. We have evaluated the efficacy of this drug in murine as well as in rat skin and soft tissue infection models using Staphylococcus aureus ATCC and clinical strains. In thigh infection model the dose of linezolid required for more than $1 \log _{10}$ kill from baseline inoculum in neutropenic mice and rats was $100 \mathrm{mg} / \mathrm{kg}$ and $50 \mathrm{mg} / \mathrm{kg}$, b.i.d/day, respectively, which was 5 and 4 folds more than that in immunocompetent animals, respectively. Dose required to achieve $1 \log _{10}$ killing was similar against different strains of $S$. aureus in immunocompetent mouse thigh infection model. However, in murine groin abscess infection model, a dose of $100 \mathrm{mg} / \mathrm{kg}$, b.i.d/day of linezolid produce static effect in 2 days, but revealed to be superior in 4 days treatment and showed approximately $1 \log _{10}$ killing from base line inoculums. Based upon pharmacokinetic profile, a 24-h AUC/MIC required for linezolid efficacy in murine groin abscess model was 91.5 for the strain used in this study. As linezolid is taken as a gold standard drug in the evaluation of new chemical entity, this data could be useful for comparing the preclinical efficacy of new anti-MRSA agents.

\section{Introduction}

Staphylococcus aureus, once largely susceptible to antibiotics, is now often resistant to multiple classes, including $\beta$-lactams, macrolides, aminoglycosides, and fluoroquinolones. ${ }^{1}$ Community acquired methicillin resistant $S$. aureus (CA-MRSA) not only causes the skin and soft tissue infection but is also responsible for highly invasive and rapidly progressive, life-threatening diseases such as necrotizing pneumonia, severe sepsis and necrotizing fasciitis. ${ }^{2}$

Linezolid, the first marketed oxazolidinone antibiotic, has broad spectrum in vitro activity against antibiotic-susceptible and resistant Gram-positive bacteria, including MRSA and $S$. aureus with intermediate resistance to glycopeptides. ${ }^{3}$ Plasma concentrations of intravenous and oral linezolid are equivalent, with average concentrations exceeding the MICs for susceptible pathogens throughout the $12 \mathrm{~h}$ dosing interval. ${ }^{4}$ The drug is indicated for complicated and uncomplicated skin infection caused mainly by $S$. aureus. ${ }^{5}$ However, the efficacy of this drug is not much assessed in animal model of skin and soft tissue infection or available data is fragmented in nature.

The objective of the present study is to evaluate and compare the efficacy of linezolid against various $S$. aureus strains in an immunocompetent and neutropenic mouse as well as rat thigh infection models and in murine groin abscess model, which is a more complicated skin and soft tissue infection model (cSSTI). Furthermore, the efficacy data is supported with the relevant pharmacokinetic data for both the species.

\section{Materials and Methods}

\section{Bacterial strains and growth conditions}

$S$. aureus L-2 and H-29 were clinical isolated and used in in vivo studies. S. aureus ATCC 25923 was purchased from the American Type Culture Collection (Manassas, Va., U.S.A). Methicillin resistant S. aureus (MRSA) 562 was obtained from Ranbaxy Research Laboratories Infectious Diseases bacterial culture collection. Isolates were grown in Trypticase soy broth (Becton Dickinson, Cockeysville, MD., U.S.A) at $37^{\circ} \mathrm{C}$

\section{Drug preparation}

Linezolid was procured from the National Chemical Laboratory (Pune, India). Vancomycin was obtained from API manufacturing facility of Ranbaxy Research Labor atories. Levofloxacin was purchased from commercial sources (Levaquin tablets, ORTHOMCNEIL Pharmaceutical Inc. Raritan, NJ). Linezolid was prepared in $0.25 \%$ methyl cellulose. Vancomycin and levofloxacin were dissolved in sterile milli- $Q$ water.

\section{Susceptibilty testing}

MICs were determined by the microbroth dilution method according to CLSI guidelines. ${ }^{6}$
Correspondence: Manoj Kumar, Ranbaxy research Laboratories, Department of Infectious Diseases, New Drug Discovery Research (R\&D 3), Plot No. 20, Sector -18, Udyog Vihar Industrial Area, Gurgaon, 122001, Haryana, India.

Tel. +91.1242342001-10X 5238 - Fax: +91.1243545. E-mail: manoj.kumar.vi@dsin.co.in

Present address: *Department of Microbiology (Biology), ${ }^{\circ}$ Drug Metabolism and Pharmacokinetics Division, Daiichi Sankyo Research Center in India, Village Sarhaul, Sector 18, Gurgaon, India.

Key words: murine thigh infection, MRSA, linezolid.

Funding: New Drug Discovery Research, Ranbaxy Research Laboratories, Gurgaon, India.

Received for publication: 25 May 2011. Accepted for publication: 10 June 2011.

This work is licensed under a Creative Commons Attribution NonCommercial 3.0 License (CC BYNC 3.0).

(C) Copyright M. Rao et al., 2011

Licensee PAGEPress, Italy

Microbiology Research 2011; 2:e3

doi:10.4081/mr.2011.e3

The MIC was defined as the lowest concentration of antibiotic that prevented visible growth after an incubation period of 18 to $24 \mathrm{~h}^{7}$

\section{Experimental animals}

Swiss albino mice (5-6 weeks old, 18-22 g weight and specific-pathogen free) and Wistar rats (4-6 weeks old, 90-110 g weight, and specific-pathogen free) were used for the studies. The experimental protocols were approved by the Institutional Animal ethics Committee (IAEC) of Ranbaxy Research Laboratories, Gurgaon, India. Animals were adapted to standardized environmental conditions for 2-3 days before the experiments.

Thigh infection was performed in immunocompetent and neutropenic animals. In each group 6 animals were taken. Animals were rendered neutropenic (neutrophils $<100 / \mathrm{mm}^{3}$ ) as described earlier by Andes et al. $;^{8}$ by injecting cyclophosphamide (Ledoxan, Dabur pharmaceuticals, New Delhi, India) at $150 \mathrm{mg} / \mathrm{kg}$ (day - 4) and $100 \mathrm{mg} / \mathrm{kg}$ (day - 1) and $100 \mathrm{mg} / \mathrm{kg}$ (day - 4) and $80 \mathrm{mg} / \mathrm{kg}($ day -1$)$ in mice and rat, respectively. For groin infection in mice the hairs were trimmed from the groin area of the animals using an electric hair clipper (TSE systems, Germany) and subsequently hair remover cream (Wyeth, USA) was applied to completely remove the hairs, a day before infection. 


\section{Pharmacokinetic study in mouse and rat}

To correlate the doses of linezolid administered to mice and rat with measures of exposure, single-dose pharmacokinetic studies were conducted with Swiss albino mice and Wister rats. Twenty-seven male Swiss albino mice were taken for the study. A dose of $5 \mathrm{mg} / \mathrm{kg}$ and $100 \mathrm{mg} / \mathrm{kg}$ of linezolid was orally administered to three mice in each group. Terminal blood samples (collected into labeled tubes containing $25 \mu \mathrm{L}$ of $20 \% \mathrm{w} / \mathrm{v}$ sodium citrate) were taken from animals at $15 \mathrm{~min}, 30$ min, 60 min, 2, 4, 8, 12, 24 and 48 h. Plasma was separated from blood samples and stored at $-70^{\circ} \mathrm{C}$ until analysis. Pharmacokinetics and oral bioavailablilty in male Wistar rats was studied at $50 \mathrm{mg} / \mathrm{Kg}$ oral. Blood was collected from three animals at $15 \mathrm{~min}, 30 \mathrm{~min}, 60 \mathrm{~min}$, 2, 4, 8, 12 and $24 \mathrm{~h}$. Plasma was separated from blood samples and stored at $-70^{\circ} \mathrm{C}$ as described above. The level of linezolid in plasma was determined by LC-MS/MS. The lower limit of quantitation (LLOQ) was $14.84 \mathrm{ng} / \mathrm{mL}$.

\section{Localized thigh infection (immuno- competent versus neutropenic)}

Thigh infection was established in both immunocompetent and neutropenic mice and rat. For infection, overnight grown culture in BHI (brain heart infusion) was adjusted to contain approximately $3 \times 10^{8} \mathrm{CFU} / \mathrm{mL}$ of $S$. aureus. The culture was diluted 1:10 in normal saline (NS) and mixed with 5\% hog gastric mucin in a $1: 1$ proportion ratio to achieve an inoculum of approximately $1.5 \times 10^{7} \mathrm{CFU} / \mathrm{mL}$. For establishing infection, $100 \mu \mathrm{L}$ and $250 \mu \mathrm{L}$ of this culture was injected intramuscularly into the right thigh of immunocompetent mice and rat, respectively.

For neutropenic animals, the initial inoculum was diluted 1:100 in NS and then mixed with $5 \%$ hog mucin in $1: 1$ ratio, to get an inoculum of approximately $1.5 \times 10^{6} \mathrm{CFU} / \mathrm{mL}$. The treatment was started $1 \mathrm{~h}$ post infection and administered twice daily by oral route for either 1 and 2 days. The efficacy of linezolid was evaluated at several dose levels. In order to determine the initial bacterial load, an early infection control $(1 \mathrm{~h})$ was dissected at the start of treatment. At the end of treatment, all groups of animals were sacrificed by cervical dislocation. The thigh muscles were dissected out under aseptic conditions and homogenized in $1 \mathrm{~mL}$ of $\mathrm{NS}$ in case of mice thigh and $5 \mathrm{ml}$ NS in case of rat thigh. The bacterial count was quantified by platting the serial dilutions of homogenate on TSA and incubating at $37^{\circ} \mathrm{C}$ for overnight.

\section{Groin abscess model}

For causing groin abscess infection, adju-

Table 1. Mean $\log _{10}$ reduction in cfu/thigh of $S$. aureus by linezolid in thigh and groin infection studies.

\begin{tabular}{|c|c|c|c|c|}
\hline Strains & $\begin{array}{c}\text { MIC } \\
(\mu \mathrm{g} / \mathrm{mL})\end{array}$ & $\begin{array}{r}\text { Mea } \\
\text { Linez } \\
\text { Day } 1 \\
(\text { Mean } \pm \text { SD) }\end{array}$ & $\begin{array}{l}\text { BID, PO } \\
\text { Day } 2 \\
(\text { Mean } \pm \text { SD })\end{array}$ & $\begin{array}{c}\text { Mean } \log _{10} \text { reduction in } \\
\text { CFU/abscesses } \\
\text { Linezolid } 100 \mathrm{mpk} \text {, BID, P0 } \\
\text { Day } 4 \\
(\text { Mean } \pm \text { SD) }\end{array}$ \\
\hline $\begin{array}{l}\text { S. aureus } \\
\text { ATCC } 25923\end{array}$ & 1 & $3.35 \pm 0.2$ & $3.92 \pm 0.62$ & ND \\
\hline $\begin{array}{l}\text { S. aureus } \\
\text { MRSA } 562\end{array}$ & 2 & $3.23 \pm 0.22$ & $3.41 \pm 0.34$ & ND \\
\hline $\begin{array}{l}\text { S. aureus } \\
\text { H-29 }\end{array}$ & 2 & $3.21 \pm 0.64$ & $3.77 \pm 0.52$ & $2.81 \pm 0.52$ \\
\hline $\begin{array}{l}\text { S. aureus } \\
\text { L-2 }\end{array}$ & 2 & $3.11 \pm 0.35$ & $3.31 \pm 0.50$ & $2.5 \pm 0.38$ \\
\hline
\end{tabular}

vant semi solid nutrient agar was prepared by suspending 0.6\% Bactoagar (Becton Dickinson and Company, Sparks MD, USA) in nutrient broth (HiMedia Laboratories, Mumbai, India) and sterilized by autoclaving. The overnight grown culture in BHI was diluted 1: 20 in normal saline and then 1:10 in $0.6 \%$ semi solid nutrient agar. The animals were injected subcutaneously with $0.5 \mathrm{~mL}$ of the prepared inoculum containing approximately $10^{6} \mathrm{CFU}$ of bacteria in the groin area.

Mice received linezolid by oral and vancomycin by subcutaneous route, b.i.d. for either 2 or 4 days. After $18 \mathrm{~h}$ of the last dose, animals were euthanized; the skin was disinfected with $70 \%$ alcohol and allowed to dry. The abscesses formed in the groin region were aseptically removed along with the skin and homogenized in $1 \mathrm{ml}$ of sterile NS. Serial tenfold dilutions of the homogenates were plated on TSA and the viable bacterial numbers were determined. Experiment was performed in duplicate and results combined for analysis.

\section{Data analysis}

The in vivo efficacy data was analysed using GraphPad Prism version 4.1 and Microsoft Excel 2007. Pharmacokinetic data was analysed with the WinNonlin software (Pharsight, Mountain View, CA, USA) program version 4.1. Linezolid efficacy data was expressed in the form of change in bacterial load per thigh from base line inoculum (bacterial load at the start of treatment).

\section{Results}

\section{Susceptibility profile of S. aureus strains and exposure study}

The minimum inhibitory concentration of $S$. aureus strains used in this study is presented in Table 1. The systemic plasma exposure pro-
Table 2. Selected pharmacokinetics parameter of linezolid estimated in Swiss albino mice.

\begin{tabular}{cccc}
$\begin{array}{c}\text { Dose } \\
(\mathrm{mg} / \mathrm{kg})\end{array}$ & $\begin{array}{c}\mathrm{C}_{\max } \\
(\mu \mathrm{g} / \mathrm{mL})\end{array}$ & $\begin{array}{c}\text { AUC } \\
(\mu \mathrm{g} \cdot \mathrm{h} / \mathrm{mL})\end{array}$ & $\begin{array}{c}\text { AUC/MIC } \\
\text { ratio }\end{array}$ \\
5 & 2.53 & 5.32 & 2.66 \\
$20^{\#}$ & 16.90 & 36.50 & 18.25 \\
\hline $40^{\#}$ & 33.72 & 73.04 & 36.52 \\
$80^{\#}$ & 67.42 & 146.08 & 73.04 \\
\hline 100 & 84.35 & 182.79 & 91.40 \\
\hline
\end{tabular}

\#Extrapolated values.

Table 3. Selected pharmacokinetics parameter of linezolid estimated in Wister rats.

\begin{tabular}{cccc}
$\begin{array}{l}\text { Dose } \\
(\mathrm{mg} / \mathrm{kg})\end{array}$ & $\begin{array}{c}\mathrm{C}_{\max } \\
(\mu \mathrm{g} / \mathrm{mL})\end{array}$ & $\begin{array}{c}\text { AUC } \\
(\mu \mathrm{g} \cdot \mathrm{h} / \mathrm{mL})\end{array}$ & $\begin{array}{c}\text { AUC/MIC } \\
\text { ratio }\end{array}$ \\
$10^{\#}$ & 3.00 & 28.00 & 14.00 \\
50 & 17.70 & 107.00 & 53.50 \\
\hline $100^{\#}$ & 29.90 & 277.00 & 138.50 \\
\hline
\end{tabular}

file of linezolid in Swiss albino mice and Wister rats following different oral doses is given in Table 2 and Table 3 respectively. The oral exposure study of linezolid in mice was performed at 5 and $100 \mathrm{mg} / \mathrm{kg}$, however, PK values of 20,40 and $80 \mathrm{mg} / \mathrm{kg}$ were extrapolated. Linezolid oral exposure study in rats was performed at $50 \mathrm{mg} / \mathrm{kg}$ and the values of 10 and $100 \mathrm{mg} / \mathrm{kg}$ were extrapolated.

\section{S. aureus thigh infection}

Four strains of $S$. aureus (ATCC 25923, MRSA H-29, MRSA L-2 and MRSA-562) were used for efficacy evaluation of linezolid in murine thigh infection model. The oral efficacy of linezolid was evaluated at a dose of 20 $\mathrm{mg} / \mathrm{kg}$, bid in 1 and 2 days murine SSTI models and summarized in Table 1. In murine SSTI model, all tested $S$. aureus strains showed good infectivity and grew from $6.3 \pm 0.25$ to $8.6 \pm 0.42$ 
$\log _{10} \mathrm{CFU} /$ thigh in day 1 and to $9.0 \pm 1.3 \log _{10}$ CFU/thigh in 2 days. The bacterial load reduction of linezolid at a dose of $20 \mathrm{mg} / \mathrm{kg}$ in thigh infection model against all tested strains is given in the Table 1. Other standard drugs vancomycin and levofloxacin (data not presented) showed more than $4 \log _{10}$ reduction from late untreated control in both studies.

\section{Efficacy in immunocompetent ver- sus neutropenic animals}

In order to access the Staphycoccal killing potential of linezolid in animal SSTI model, a detail efficacy study against $S$. aureus ATCC 25923 was performed in immunocompetent and neutropenic mice and rats thigh infection model. In immunocompetent infection model in mice with a sensitive strain, $S$. aureus ATCC 25923, linezolid exhibited more than $3 \log _{10}$ reduction compared to the late untreated controls ( $>1 \log _{10}$ killing from initial inoculum) at the dose of $20 \mathrm{mg} / \mathrm{kg}$ BW, bid/day. However, in murine neutropenic thigh infection model the drug showed the similar effect only at a higher dose of $100 \mathrm{mg} / \mathrm{kg} \mathrm{BW}$, bid/day, stasis at 80 $\mathrm{mg} / \mathrm{kg} \mathrm{BW}$, bid/day (Figure 1). A Similar efficacy of linezolid was observed in Wistar rats. A dose of $10 \mathrm{mg} / \mathrm{Kg} \mathrm{BW} \mathrm{bid/day} \mathrm{showed}>1 \log _{10}$ killing from initial CFU in immunocompetent rats, whereas in neutropenic rats a dose of 50 $\mathrm{mg} / \mathrm{kg} \mathrm{BW}$, b.i.d./day is required to get similar efficacy (Figure 2).

\section{S. aureus groin abscess model}

The efficacy of linezolid was determined in groin infection model with virulent MRSA strains, L-2 and H-29 (Table 1). Using 0.6\% agar as an adjuvant, the efficacy of linezolid was evaluated at several doses (Figure 3). A dose of $100 \mathrm{mg} / \mathrm{kg}$ b.i.d. showed static effect in 2 days model, while in 4 days treatment approximately $1 \log _{10}$ killing from base line inoculum was achieved at the same dose (Figure 3).

\section{Discussion}

Complicated skin and soft tissue infections (cSSTI) caused by $S$. aureus are frequently encountered in clinical practice and are the significant cause of morbidity and mortality in hospitalized patients. Linezolid is the first oxazolidinone that inhibits the bacterial protein synthesis. It possesses a broad spectrum of in vitro and in vivo activity against both community and nosocomial Gram-positive pathogens. ${ }^{9}$ Of the many indications for which the drug has been approved, SSTI and cSSTI caused by MSSA and MRSA strains are the main area where the drug has demonstrated clinical efficacy. ${ }^{5,9}$

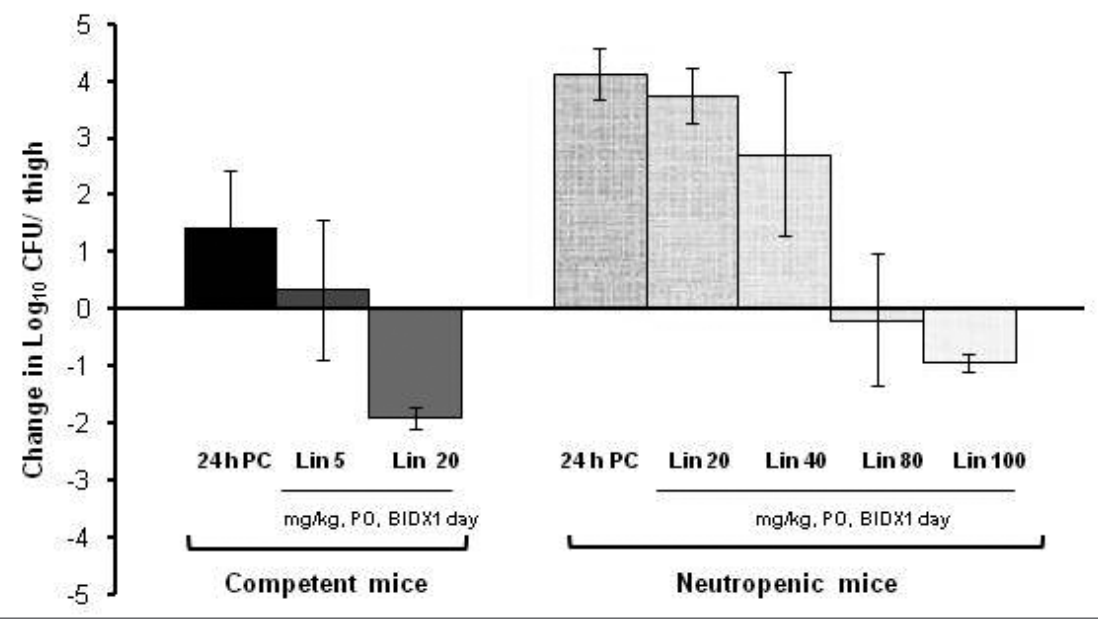

Figure 1. Comparison of linezolid efficacy in immunocompetent mice at 5 and $20 \mathrm{mg} / \mathrm{kg}$ dose) and in immunocompromised mice at 20, 40, 80 and $100 \mathrm{mg} / \mathrm{kg} \mathrm{BW} \mathrm{dose)} \mathrm{in} \mathrm{thigh}$ infection model of $S$. aureus 25923.

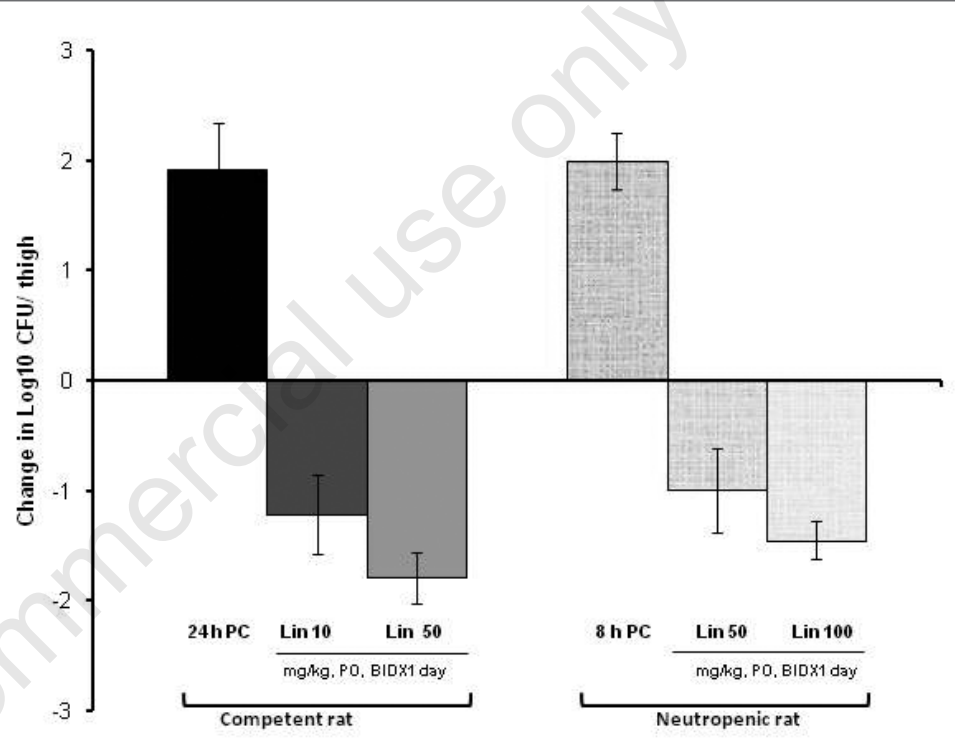

Figure 2. Comparison of linezolid efficacy in immunocompetent rat at 10 and $50 \mathrm{mg} / \mathrm{kg}$ dose) and in immunocompromised rat at 50 and $100 \mathrm{mg} / \mathrm{kg} \mathrm{BW}$ dose) in thigh infection model of $S$. aureus 25923.

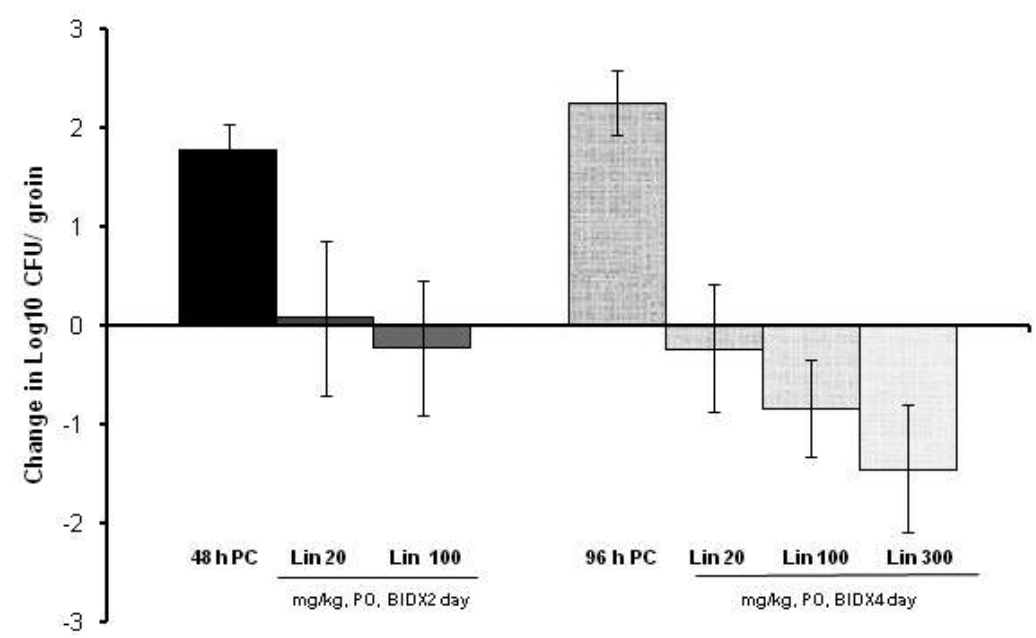

Figure 3. Comparison of linezolid efficacy in mice groin abscess infection model against S. aureus L-2, Bid $\mathrm{x} 2$ and 4 days. 
In the preclinical lead optimization or drug discovery, linezolid is taken as a gold standard for comparing novel compounds against $S$. aureus especially in SSTI and cSSTI models. But limited preclinical data is available on the in vivo efficacy of linezolid. ${ }^{10,11}$ Further, the published data of linezolid on the animal models of SSTI against $S$. aureus is scarce.

Pucci et al. ${ }^{11}$ studied the preclinical efficacy of linezolid at $20 \mathrm{mg} / \mathrm{kg}$ in neutropenic murine thigh infection and failed to achieve any bacterial $\log _{10}$ reduction from initial control. In the present study the efficacy of linezolid was tested at various concentrations against different MSSA and MRSA including the L strain in immunocompetent and neutropenic murine thigh infection. Linezolid showed more than 1 $\log _{10}$ killing from initial-control in immunocompetent mice and more than $3 \log _{10}$ from late infection control at $20 \mathrm{mg} / \mathrm{kg}$, P0, b.i.d. X 1 day. Based on the AUC obtained in our exposure study, a dose of $20 \mathrm{mg} / \mathrm{kg}$, BW bid/day gives a 24-h AUC/MIC 18.25. This is a minimum necessary dose for linezolid efficacy against $S$. aureus in cSSTI in immune-competent mice, while a 24 -h AUC/MIC ratio required to produce a static effect in neutropenic mice against $S$. aureus (91.4) was 5- fold greater than those observed in immunocompetent mice. A dose of $80 \mathrm{mg} / \mathrm{kg}$ was required to achieve stasis and $1 \log _{10}$ killing from initialcontrol was achieved with a dose of $100 \mathrm{mg} / \mathrm{kg}$ in neutropenic mice. This observation was also correlated well with rat thigh infection model, in which a 24-h AUC/MIC ratio required to achieve approximately $1 \log _{10}$ reduction from initial control in neutropenic rat was 4 times higher than that required in immunocompetent rat against $S$. aureus (Table 3). Our results are in line with that reported by Andes et al. ${ }^{8}$ a 24-h AUC/MIC as the key parameter which determines efficacy in neutropenic mice and the ratio of 90 - 100 is required for the $S$. aureus strains with an in vitro MIC of 1-2 $\mu \mathrm{g} / \mathrm{mL} .{ }^{8}$ Also this AUC best correlates with the levels achieved in humans after the recommended $600 \mathrm{mg}$ b.i.d. dose for SSTI infections. ${ }^{2}$ Moreover, we have showed the detailed efficacy study of linezolid against different clinical isolates of $S$. aureus and also dose response in immunocompetent and neutropenic mice and rats SSTI models.

According to a previous report, prevention of abscess formation by antibiotic treatment based upon the minimal inhibitory concentra- tion (MIC) of an antibiotic for $S$. aureus was not as predictable as of antibiotic cure in a systemic-lethal $S$. aureus infection in mice. ${ }^{12}$ Previous animal models of subcutaneous abscess which have been described have used various abscess promoting agents such as cytodex microcarrier beads ${ }^{10,12}$ and soft agar. ${ }^{13}$ The efficacy in these models denoted as $\mathrm{ED}_{50}$, was described as the amount of antibiotic required to eradicate $50 \% S$. aureus in murine groin abscess infection model from baseline inoculum. Using cytodex in one of the early in vivo studies of linezolid, Ford et al. (1996) ${ }^{12}$ showed that linezolid was moderately active with ED50 of $39.0 \mathrm{mg} / \mathrm{kg}$ when dosed bid, for 5 days in murine soft tissue infection model with $S$. aureus UC9271 (clinical isolate).

The present study evaluates the efficacy of this drug in groin abscess model using agar as an adjuvant and the data are correlated with the plasma exposure levels in mice. In our groin infection study the drug was static as it reduced the organ load just below or to the baseline inoculum. Furthermore, $\log _{10}$ reduction values reported here correlate well with a recent study by Hilliard et al. ${ }^{14}$ In their study the efficacies of linezolid, and vancomycin were described in a staphylococcal skin infection model with CA-MRSA using cytodex as adjuvant. Linezolid showed 2.1 to $2.9 \log _{10}$ reductions from controls at a dose range of 20 to $320 \mathrm{mg} / \mathrm{kg}$, respectively over the 2 days treatment period and vancomycin was more efficacious than linezolid at higher doses.

In conclusion, our current studies demonstrate that activity of linezolid is affected by the neutrophenia. For groin infection models and neutropenic thigh, stasis can only be achieved with doses as high as $100 \mathrm{mg} / \mathrm{Kg}$, bid per day. The different efficacy models described in this paper provide the benchmark doses of linezolid that can be taken for comparison, while evaluating the new chemical entity for cSSTI target product profile in anti-infective drug discovery.

\section{References}

1. Barrett JF. MRSA- What is it, and how do we deal with the problem? Expert Opin Ther Targets 2005;9:253-65.

2. Mongkolrattanothai K, Boyle S, Kahana MD, Daum RS. Severe Staphylococcus aureus infections caused by clonally related community-acquired methicillin-susceptible and methicillin-resistant isolates. Clin Infect Dis 2003;37:1050-8.

3. Moellering R. Linezolid: The first oxazolidinone antimicrobial. Ann Intern Med 2003;138:135-42.

4. Hamel JC, Stapert D, Moermann JK, Ford CW. Linezolid, Critical characteristics. Infection 2000;28:60-4.

5. Food and drug administration. FDA approves Zyvox, the first antimicrobial drug in a new class. Rockville: National Press Office. 2000;T00-17.

6. Methods for Dilution Antimicrobial Susceptibility Tests for Bacteria that Grow Aerobically. Wayne: Clinical and Laboratory Standards Institute; 2006.

7. Barman TK, Pandya M, Mathur T, et al. Novel biaryl oxazolidinones: in vitro and in vivo activities with pharmacokinetics in an animal model. Int J Antimicrob Agents 2009;33:280-4.

8. Andes D, van Ogtrop ML, Peng J, Craig WA. In vivo pharmacodynamics of a new oxazolidinone (Linezolid). Antimicrob Agents Chemother 2002;46:3484-9.

9. Linden P. Use of linezolid for Gram-positive infections. Infect Med 2002;19:25-32.

10. Ford CW, Hamel JC, Stapert D, Yancey RJ. Establishment of an experimental model of a Staphylococcal aureus abscess in mice by use of dextran and gelatin microcarriers. J Med Microbio 1989;28:259-66.

11. Pucci MJ, Cheng J, Podos SD, et al. In vitro and in vivo antibacterial activities of heteroaryl isothiazolones against resistant gram positive pathogens. Antimicrob agents Chemother 2007;51:1259-67.

12. Ford CW, Hamel JC, Wilson DM, et al. In vivo activities of U-100592 and U-100766, novel oxazolidinone antimicrobial agents, against experimental bacterial Infections. Antimicrob Agents Chemother 1996;40: 1508-13.

13. Fujimoto T, Sato M, Katami K, et al. Chemotherapeutic efficacy of ofloxacin on renal and subcutaneous infection models with Staphylococcus aureus in mice. Chemotherapy 1986;32:291-8.

14. Hilliard JJ, Fernandez J, Melton J, et al. In vivo activity of the pyrrolopyrazolylSubstituted oxazolidinone RWJ-416457. Antimicrob Agents Chemother 2009;53: 2028-33. 